\title{
Liikuntapolitiikka kaipaa intersektionaalista ohjausta
}

\author{
$+y$ \\ Intersektionaalisen ryhmäliikuntapedagogiikan avulla \\ liikuntapalveluita voidaan kehittää vastaamaan \\ paremmin aikuiskoulutuspolitiikan sivistyksellisiä ja \\ työelämälähtöisiä päämääriä.
}

\begin{abstract}
AIKUISKOULUTUSJÄRJESTELMÄN KEHITYKSEN painopisteet ovat 2000-luvulla paikantuneet työelämälähtöisesti tutkintojen ja ammatillisen koulutuksen alueelle (Leveälahti ym. 2015). Omaehtoinen harrastetoiminta sivistyspäämäärineen on jäänyt aikuiskoulutuspolitiikan keskusteluissa vähemmälle huomioille. Yksi tällainen nonformaalin ja informaalin oppimisen konteksti on ohjattu aikuisten kuntoliikunta. Sen puitteissa edistetään yksilöiden persoonallisuuden kehittymistä, aktiivista kansalaisuutta, yhteisöllisyyttä, osallisuutta ja moniarvoisuutta (Itkonen \& Kauravaara 2015). Lisäksi liikunnanohjaajat välittävät asiakkailleen liikuntaharrastuksen organisoimisen ohella liikunta- ja terveystietoa (Markula \& Chikinda 2016).

Vielä 2010-luvullakin liikunta on usein liitetty kollektiivisiin, elinkeinoelämän tarpeista nouseviin työkykyisyyden, jatkuvan oppimisen ja työssäjaksamisen teemoihin. Liikuntaharrastuksista on tullut yksilöille tapa ilmentää kunnon kansalaisuutta ja keino
\end{abstract}

pitää yllä markkina-arvoa työntekijänä (Ayo 2012). Liikunta onkin kenttä, jolla on sekä merkittävä sivistystehtävä että rooli tuottavuuden ja taloudellisten päämäärien edistäjänä. Liikunnan merkitys fyysiselle ja psyykkiselle hyvinvoinnille on yleisesti tunnustettu.

Aikuiskoulutuspolitiikan keskeinen oletus on, että jokaisella yksilöllä tulee olla oikeus osallistua koulutukseen ja itsensä kehittämiseen omien kykyjensä mukaisesti. Sivistykselliset oikeudet itsensä kehittämiseen ulottuvat mahdollisuuteen harjoittaa liikuntaa (Pyykkönen 2016, 17).

Lukuisat liikuntatutkimukset ovat osoittaneet, että aikuisten liikuntakulttuuri sisältää eriarvoistavia ja yksilöitä ulossulkevia mekanismeja (Harjunen 2019; Kauravaara \& Rönkkö 2020; Kokkonen 2018). Tulokset asettavat kyseenalaiseksi, pystyvätkö liikunnan järjestäjät tarjoamaan kaikille aikuisväestöön kuuluville yhtäläiset mahdollisuudet osallistua liikunnan oppimiskonteksteihin. 
Kysymme ensiksi, miten liikunnan yhdenvertaisuutta on pyritty edistämään valtiollisen politiikan keinoin ja toiseksi, millaisia ongelmia edistämistavoitteissa on havaittu. Tapausesimerkkimme, ryhmäliikunta, on merkittävä aikuisten vapaa-ajan liikuntakonteksti. Tilastokeskuksen vuonna 2017 toteuttaman vapaa-aikatutkimuksen mukaan joka kahdeksas suomalainen käy säännöllisesti ohjatuilla ryhmäliikuntatunneilla (Ruuskanen 2019).

Näkemyksemme mukaan liikuntakulttuurin yhdenvertaisuus vaatii sekä valtion ohjauksen että ruohonjuuritason ryhmäliikuntaohjaamisen osalta yhä täsmällisempää intersektionaalisiin eroihin fokusoivaa otetta. Tutkimuksellisen otteen lisäksi tarkastelemme liikunnan kenttää oman ryhmäliikuntaalan työkokemuksemme pohjalta.

\section{LIIKUNTASEKTORIN JULKINEN OHJAUS}

Valtionohjauksen tapoja ovat informaatio-, resurssija säädösohjaus, joita käytetään rinnakkain ja toisiaan tukien. Liikuntapolitiikassa tämä tarkoittaa, että aikuisten liikuntaa edistetään tutkimustiedon, valtionavustusten sekä lainsäädännön avulla.

Lait ohjaavat toteutettua liikuntapolitiikkaa erityisesti julkisella sektorilla. Liikuntalaki (2015) pyrkii tukemaan eri väestöryhmien liikuntamahdollisuuksia, liikuntaan ja urheiluun liittyvää kansalaistoimintaa sekä väestön hyvinvointia ja terveyttä. Liikuntalain muutokset 1970-luvun lopulta 2010-luvulle kertovat yhdenvertaisuusajattelun kehityksestä liikuntakentällä (Pyykkönen 2016, 14).

Vuonna 2015 voimaan tulleen liikuntalain lähtökohtina ovat tasa-arvo, yhdenvertaisuus, yhteisöllisyys, monikulttuurisuus, terveet elämäntavat ja kestävä kehitys. Liikuntakeskusteluissa viitataan säädösten osalta yleensä juuri liikuntalakiin, vaikka valtion liikuntapolitiikassa yhdenvertaisuutta edistetään monin muinkin, liikuntalakia velvoittavammin asetuksin ja laein (Pyykkönen 2016, 14).

Yhdenvertaisuuslain (2014) tavoite on ehkäistä syrjintää ja tehostaa sen kohteeksi joutuneen oikeusturvaa. Euroopan unionin jäsenyyden myötä säädetty yhdenvertaisuuslaki kieltää syrjinnän henkilöä koskevien ominaisuuksien, kuten iän, alku- perän tai terveydentilan, perusteella (Nousiainen 2012, 151). Laissa linjataan, että viranomaisilla, koulutuksen järjestäjillä ja työnantajilla on velvollisuus edistää yhdenvertaisuutta. Lakia on kehitetty ennakoivaan suuntaan, ja se edellyttää, että eri tahoilla tulee olla suunnitelma yhdenvertaisuuden edistämisen toimista sekä arviointia edistämistoimien vaikuttavuudesta.

Resurssiohjaus eli taloudellinen ohjaus valtionavustuksilla on ollut keskeinen tapa edistää liikunnan yhdenvertaisuutta. Valtion talousarvioon on otettu vuosittain määräraha liikuntajärjestöjen ja lajiliittojen toiminnan avustamiseen. Vuoden 2020 valtion talousarviossa liikuntaan ja huippu-urheiluun on varattu noin 166 miljoonaa euroa. Valtionavustuksilla liikuntajärjestöt ovat voineet esimerkiksi palkata yhdenvertaisuustyöstä vastaavaa henkilöstöä.

Ennen vuotta 2020 opetus- ja kulttuuriministeriön (OKM) valtionavustusten myöntöperusteena järjestöiltä vaadittiin yhdenvertaisuus- ja tasa-arvosuunnitelmaa (Pyykkönen 2016, 35). Vuonna 2020 voimaan tulleissa valtionavustuskriteereissä ohjaus on velvoittavampaa, ja vastuullisuus on merkittävässä asemassa: yhdenvertaisuuden ja tasa-arvon toteuttamisen puutteista järjestön tai lajiliiton avustusosuus pienenee. Toimijoilta edellytetään aktiivista tasa-arvon ja yhdenvertaisuuden edistämistä. Koska yhdenvertaisuus on käytännön liikuntatyössä usein mielletty pikemminkin arvotavoitteeksi kuin ehdottomaksi lähtökohdaksi, asiaan on haluttu puuttua.

Valtion liikuntaneuvoston selvityksen perusteella liikunnan yhdenvertaisuuteen kohdistunut arviointi on aiemmin 2000-luvulla ollut vähäistä. Liikuntaviranomaisia, liikuntakoulutuksen järjestäjiä tai liikunta-alan työnantajia ei ole arvioitu sen perusteella, miten heidän toimintansa toteuttaa yhdenvertaisuutta ja tasa-arvoa. (Pyykkönen 2016, 35.)

Haastavaa on ollut se, ettei liikuntalaissa tai liikunta-asetuksissa avata tarkemmin sitä, miten tasa-arvo ja yhdenvertaisuus tulisi käytännössä huomioida liikunta-arjessa. Kun kattava valvonta puuttuu eivätkä liikunnan hyvät käytännöt ole vakiintuneita, monet välillisen ja piiloisen syrjinnän muodot saattavat elää toimintakulttuureissa vahvasti lakiin perustuvista syrjintäkielloista huolimatta. Yhdenvertaisuutta 


\section{LAINSÄÄDÄNNÖSS̈̈}

EI M $\ddot{A} \ddot{A} R T E L L \ddot{A}$,

MITEN TASA-ARVO JA

YHDENVERTAISUUS TULISI

K ̈̈YT ̈̈NNÖSS $\ddot{A}$ HUOMIOIDA

LIIKUNTA-ARJESSA.

oikeudellisesta näkökulmasta tarkastelleet selvitykset viittaavat siihen, että syrjinnän on oltava tietoista ja tahallista ennen kuin siihen osataan, voidaan tai halutaan puuttua (Nousiainen 2012, 145).

Toisena keskeisenä haasteena on pidetty sitä, että suomalainen liikuntakenttä on jakautunut monella tasolla esimerkiksi lainsäädännön, rahoituspohjan ja työnjaon vuoksi. Valtion, kuntien ja järjestöjen tavoitteet ovat periaatetasolla samanlaiset, mutta vastuu liikunnan yhdenvertaisuuden toteuttamisesta on käytännössä pirstoutunut niin, ettei se itsestään selvästi kuulu kenellekään. (Pyykkönen 2016, 36.)

Huippu-urheilu, lajiliitot, naisliikunta ja erityisliikuntajärjestöt tarkastelevat yhdenvertaisuuden tilaa omista näkökulmistaan ja toimivat toisistaan erillään. Vaikka organisaatiot ovat yhteisellä liikunnan asialla, ne joutuvat kilpailemaan keskenään resursseista. (Pyykkönen 2016, 32.) Yhdenvertaisuustyön projektiluonteisuus ja hankemuotoisuus tekee usein systemaattisen, pitkäaikaisen sitoutumisen yhdenvertaisuuspyrkimyksiin vaikeaksi (Hokka 2014, 26).

\section{INTERSEKTIONAALISUUS VASTUULLISEN LIIKUNTAPOLITIIKAN TYÖKALUNA}

Intersektionaalisuuden käsitteellä viitataan siihen, että ihmisen asemaan yhteiskunnassa vaikuttavat samanaikaisesti useat tekijät, kuten sukupuoli, ikä, luokka, uskonto, etnisyys, asuinpaikka, koulutus, tulotaso, kyvykkyys, terveydentila ja seksuaalinen suuntautuminen. Erojen ja niihin liitettyjen ennakkoluulojen sekä arvostusten takia ihmisiä kohdellaan eri tavoin. Käsitteen avulla tarkastellaan, kuinka ihmisten etuoikeudet ja eriarvoisuudet muodostuvat. (Saresma 2018.)
Termin lanseerasi juristi ja kansalaisoikeusaktivisti Kimberlé Crenshaw (1989). Hän havaitsi, että kahden syrjivän rakenteen, rasismin ja seksismin, kohdatessa yksilön syrjintä on monitahoista ja vaikeasti eriteltävissä perinteisin käsittein. Aikuiskoulutuksen alalla intersektionaalisten erojen uraauurtavat tutkimukset ovat keskittyneet luokan ja sukupuolen risteymien tarkasteluun (Skeggs 1997; Thompson 2000). Liikuntakulttuurintutkijat ovat muun muassa pohtineet sitä, miten rodun ja sukupuolen yhteisvaikutukset muokkaavat urheilijoiden harjoittelukokemuksia ja asemia (Simien ym. 2019).

Suomalaisessakin lainsäädännössä ja raporteissa epäsuorasti intersektionaalisuuteen viittaavia mainintoja on esiintynyt. Esimerkiksi vuoden 2010 valtioneuvoston selonteossa naisten ja miesten välisestä tasa-arvosta todetaan, että ”on tärkeää kiinnittää erityistä huomiota sukupuoleen ja muihin syrjintäperusteisiin liittyvään risteävään ja moniperusteiseen syrjintään” (VNS 7/2010 vp).

Toisaalta vastuullista liikuntakulttuuria pyrittiin rakentamaan vielä vuoden 2011 Suomen liikunta ja urheilu ry:n oppaassa Näköaloja laaja-alaisiin tasa-arvokysymyksiin. Kaikkien tasavertainen oikeus liikuntaan ja urheiluun (ks. Koivisto 2011) puhumalla nimenomaan laaja-alaisesta tasa-arvotyöstä. Se osoittaa, että liikuntahallinnossa yhdenvertaisuus oli melko uusi käsite 2010-luvulla eikä siksi vielä ollut juurtunut käyttöön.

Sittemmin yhdenvertaisuuden käsitteen yhteydessä on tullut tavaksi listata erilaisia henkilöön liittyviä eroja (Hokka 2014, 9). Vaikuttaa siltä, että yhdenvertaisuuden käsitteellä saatetaan joskus kuitata poliittisen korrektiuden hengessä erokategorioita, joiden yhteisvaikutusten analyysin ei ole aikomustakaan paneutua.

Liikuntapolitiikkaa on tehty ensisijaisesti väestöryhmiin perustuvien luokittelujen avulla. Ryhmittelyperusteista politiikkaa on kuitenkin kritisoitu, koska jokaisen ryhmän sisällä voi olla vähemmistöjä. (Pyykkönen 2016, 31-32.) Intersektionaalinen ote vie näkökulman homogeenisten ryhmien oletusta pidemmälle, sillä sorrettujen ryhmien listaamisen sijasta se fokusoi erontekojen kontekstisidonnaisuuteen ja erojen yhteisvaikutuksiin.

Ryhmäliikunnassa huomio kiinnittyy esimerkiksi siihen, että tunnilla valkoihoisen, urheilijataustaisen 
LIIKUNTAPOLITIIKKAA

\section{ON TEHTY ENSISIJAISESTI \\ VÄESTÖRYHMIIN}

\section{PERUSTUVIEN}

LUOKITTELUJEN AVULLA.

miehen liikuntakokemus muodostuu todennäköisesti hyvin erilaiseksi kuin tummaihoisen, huivia käyttävän, itsensä kömpelöksi ja lihavaksi tuntevan naisen, joka vasta tutustuu länsimaiseen ryhmäliikuntaharrastukseen. Yksi liikkuja voi nauttia moninkertaisesta etuoikeudestaan samalla kun toinen kohtaa moninkertaisesti ulossulkevat käytännöt ja normit. Risteävien erojen yhteisvaikutukseen fokusoiminen tekee ymmärrettävämmäksi, miksi liikunta ei anna kaikille samoja mahdollisuuksia, vaikka liikuntapalveluita tarjoiltaisiinkin eri kohderyhmille.

Vuoden 2020 lopulla on otettu askeleita suomalaisen liikuntakulttuurin eriarvoisuuksien intersektionaalisen ymmärtämisen lisäämiseksi (ks. Kauravaara \& Rönkkö 2020). Huomiomme mukaan erokategorioita kaavamaisesti selittävien esitysten houkuttavuus ei poista sitä tosiasiaa, että liikunnan arjessa syrjintäkokemukset ilmenevät usein yli ja ohi vakiintuneiden kohderyhmäjaotteluiden. Intersektionaalisuusajatteluun on olennaista sisällyttää kontekstisidonnaisten prosessien analyysia sekä pyrkimys irrottautua liikkujaryhmittelyistä. Erilaisten intressiryhmien määrän ja yhteiskunnallisen keskustelun moniäänisyyden lisääntyessä paine kohdistuu liikuntakenttään, jonka odotetaan palvelevan yhtäaikaisesti yhä useampia väestöryhmiä.

Moniperusteista syrjintää on hankalaa torjua ilman täsmällistä, vakiintunutta terminologiaa. Liikuntakäsitteissä on esiintynyt määritelmiin perustuvia sekaannuksia, mikä on tehnyt näkyväksi sen, että käytetyillä käsitteillä ja niiden ymmärtämisellä on suuri merkitys liikuntakulttuurille ja -politiikalle (Tiihonen 2014). Täten on tervetullutta, että 'intersektionaalisuus' otettiin suorasanaisesti käyttöön pääministeri Sanna Marinin (sd.) hallituksen tasa-arvo- ohjelmassa vuosille 2020-2023. Siinä todetaan, että tasa-arvon edistäminen edellyttää intersektionaalista näkökulmaa (VN 2020). Valtamedioissa debatoitu intersektionaalisuuden käsite lisäsi tietoisuutta moniperusteisen syrjinnän ilmiöstä, joten sen soisi rantautuvan liikuntapoliittiseenkin keskusteluun.

Liikunnan yhdenvertaisuutta on edistetty kansallisen liikuntapolitiikan ulkopuolellakin. Kesäkuussa 2020 Black Lives Matter -mielenosoitusten myötä uusiseelantilainen Les Mills -ryhmäliikuntayritys julisti lisäävänsä eri etnisistä taustoista tulevien ohjaajien osuutta ohjausmateriaaleissa, uudistavansa rekrytointikäytäntöjä ja ottavansa käyttöön oman syrjimättömyyssäännöstönsä. Les Mills kattaa maailmanlaajuisesti 140000 ryhmäliikuntaohjaajaa, jotka liikuttavat 20000 liikuntakeskuksessa asiakkaita päivittäin (www.lesmills.com). Merkittävää tapauksessa oli liikuntajätin tarttuminen ajankohtaiseen poliittiseen keskusteluun. Yleisen keskustelun viriämistä voitaneen pitää hyväenteisenä merkkinä eroille sensitiivisten ajattelu- ja toimintatapojen rantautumisesta liikuntakentälle.

Liikunta-alalla intersektionaalisuusajattelu yleistynee markkinaehtoisesti. Selvitysten mukaan kuluttajat ovat valmiita maksamaan enemmän vastuullisista palveluista. Toimimalla vastuullisesti palveluntarjoaja voi lisätä tuotteen arvoa ja positiivista brändiä mutta myös parantaa työnantajaimagoaan. (Trudel \& Cotte 2009.) Markkinointiviestintätoimisto Milttonin (2017) tutkimuksen mukaan suomalaiset haluavat yritysten osallistuvan julkiseen keskusteluun ja yhteiskunnallisten ongelmien ratkaisemiseen. Kun kestävät kulutusratkaisut kasvattavat suosiotaan, ryhmäliikunnassakaan ei enää riitä pelkkä fyysisiin suoritteisiin keskittyvä palvelulogiikka, vaan on satsattava liikkujien yhdenvertaisuuteen.

\section{LIIKUNNAN OHJAAMINEN RUOHONJUURITASOLLA}

Ydinkysymyksenä yhdenvertaisuuden valtavirtaistamiseksi suomalaiseen liikuntakulttuuriin on pidetty sitä, miten opitaan tunnistamaan liikunnan ulossulkevat rakenteet ja suvaitsemaan erilaisuutta (Pyykkönen 2016, 5). Siirtymä liikuntapolitiikasta ruohonjuuritason arkitodellisuuteen on ollut kuitenkin takkuinen. 
Keskustelu eettisistä kysymyksistä on vielä monelle liikuntaorganisaatiolle vierasta ja vastahakoiseksi koettu työlisä. Toiminta voi jäädä sitoutumattomaksi, jos eettisiin ulottuvuuksiin puututaan vain ulkoisen paineen tai pakon takia. (Kokkonen 2020, 11.)

Politiikka-asiakirjojen linjausten ja ruohonjuuritason väliset erot onkin pantu merkille. Asiakirjojen ongelmaksi on nimetty niiden liiallinen yleisluonteisuus ja vastuunjaon epämääräisyys. (Itkonen \& Kauravaara 2015 , 173.) Liikunnanedistäjien toimetkaan eivät välttämättä kohtaa liikkujien arkea, koska liikuntapalvelut on usein suunniteltu liikunnanedistäjien arvomaailmasta ja oletuksista käsin. Sinänsä hyvää asiaa ajavat politiikat törmäävät liikkujien ja liikunnan järjestäjien välisiin kulttuurisiin kuiluihin. (Itkonen \& Kauravaara 2015, 168.)

Julkinen ohjaus ei ole toteuttanut liikunnan yhdenvertaisuuspyrkimyksiä toivotulla tavalla. Tutkimukset osoittavat, että esimerkiksi maahanmuuttajatausta (Zacheus ym. 2011), kehon koko (Harjunen 2019) tai seksuaalivähemmistöön kuuluminen (Kokkonen 2018) tuottavat aikuisten liikuntakulttuurissa ulossulkemisia, vähättelyä ja syrjintää. Keväällä 2020 alkaneen koronaepidemian poikkeustoimet toivat yhä näkyvämmäksi sen, että liikuntamahdollisuudet jakautuvat epätasaisesti eri ihmisryhmien välillä (VN 2020:19).

Liikuntaharrastuksissa koettu eriarvoisuus voi tuottaa esimerkiksi uskon puutetta omiin kykyihin, itselle mieluisista liikuntamuodoista luopumista, liikuntapelkoa tai henkistä turvattomuutta liikuntatiloissa. Olennaista on ymmärtää, etteivät liikkujia eriarvoistavat käytännöt ole liikunnan marginaali-ilmiö. Sen sijaan ne ovat laajoja, instituutioiden rakenteisiin kytkeytyviä ongelmia, joita liikkujat kohtaavat liikuntaharrastuksissaan. (Kauravaara \& Rönkkö 2020, 230-231.)

\section{ETIIKKA KUULUU LIIKUNNANOHJAUKSEEN}

Valmentamisen etiikasta ja valmentajan vastuusta on käyty viime aikoina vilkasta keskustelua. Alkuvuonna 2020 kohu nuorten muodostelmaluisteluvalmentajan toimintatavoista sai useiden lajien tunnettuja urheilijoita ottamaan kantaa valmennuskulttuurin epäkohtiin ja kertomaan omista kokemuksistaan. Samaan aikaan Nuorisotutkimusseura julkaisi artik- kelikokoelman, joka käsitteli syrjintää, epäasiallista kohtelua sekä seksuaalista häirintää lasten ja nuorten liikunnassa (Berg ym. 2019). Myös Liikunta ja tiede -lehti keskittyi teemanumerossaan liikuntakulttuurin etiikkaan ja tarjosi filosofian keinoja hyvän valmentajuuden määrittelyyn (Kuusela 2020).

Liikunnan tasa-arvo on saavutettu puheissa, mutta käytännön toiminnassa se ei aina näy (Pyykkönen 2016, 26). Vaikuttaa siltä, että liikkujien erilaisia lähtökohtia ei pystytä huomioimaan liikunnan arjessa, vaikka tutkimustietoa, eettisiä linjauksia ja yhteiskunnallisia normeja hyvistä käytännöistä on saatavilla.

Syitä voidaan etsiä liikunnanohjaajien koulutuksesta. Kanadan kontekstissa liikuntakasvatukseen ja kehokulttuuriin perehtyneet Pirkko Markula ja Jocelyn Chikinda (2016) ovat osoittaneet, että ryhmäliikuntaohjaajien sertifiointi- ja koulutusjärjestelmä perustuu kapea-alaiseen tietoon, joka normalisoi tiettyjä tapoja ymmärtää terveyttä ja ihmiskehoa. He toteavat, että liikunnanohjauskäytännöissä biolääketieteellinen tieto on yliedustettuna. Liikunta mieltyy mekaaniseksi kehoon kohdistuvaksi toimenpiteeksi, jonka tavoite on ennaltaehkäistä sairauksia. Vastaava biolääketieteellisen määrittelyn keskeisyys on ollut havaittavissa Suomessakin muun muassa siinä, miten liikuntapolitiikka on rakentunut terveysuhkien torjunnan varaan (Pyykkönen 2016, 32).

Biolääketieteelliseen tietoon keskittyminen on puutteellista, koska liikuntapalvelut tuotetaan aina yhteydessä kokemuksellisiin liikkuviin kehoihin. Ohjaajat ovat tekemisissä kokevan subjektin kanssa, eikä ohjaustoimien kohdetta voi siten typistää vain fysiologiaan. Empiiristen tutkimusten mukaan valtaosa ohjaajien oppimisesta tapahtuu muodollisen ohjaajakoulutuksen ulkopuolella, jolloin on todennäköistä, että biolääketieteelliseen tietoon perustuvat ohjauslähtökohdat uusinnetaan kokeneilta ohjaajilta mallia otettaessa. (Parviainen 2018, 359, 362.)

Ongelmallisella tavalla myös uusliberalistinen eetos kuljetetaan liikunta- ja hyvinvointikentälle. Markkinaorientoituneessa ajassa yksilön odotetaan kantavan vastuuta omasta terveydestään. (Ayo 2012.) Liikunta-ammattilaiset eivät ota kantaa sosiaaliseen eriarvoisuuteen, eikä yksilöiden terveyteen vaikutta- 


\section{MARKKINAORIENTOITUNEESSA}

\section{AJASSA YKSILÖN ODOTETAAN}

KANTAVAN VASTUUTA OMASTA

TERVEYDEST $\dddot{A} \dddot{A} N$.

via yhteiskunnallisia tekijöitä huomioida riittävästi liikunta- ja terveyspalveluiden piirissä. Yksilöpsykologiaa korostavien motivointikeinojen ohella vedotaan terveyden estetiikkaan: tervettä kehoa kannattaa tavoitella, koska se näyttää kauniilta ja täyttää vallitsevat ulkonäköihanteet. (Markula \& Chikinda 2016.)

Koulutusjärjestelmät vahvistavat biolääketieteellistä ja terveyden estetiikkaan liittyvää uusliberalistisesti värittynyttä tietoa. Ohjaajat eivät opi koulutuksensa puitteissa tunnistamaan näiden ajattelutapojen eettisiä ongelmia tai keinoja ajatella terveyttä ja ihmiskehoa toisin. Markulan ja Chikindan (2016) johtopäätös on, että ohjaajien koulutusjärjestelmän tietopohjaa on laajennettava niin, että ohjaajien saama koulutus auttaa heitä kyseenalaistamaan vallitsevan hyvinvointitiedon valtamekanismeja ja vastustamaan ohjauskäytännöissä tapahtuvaa syrjintää.

\section{SYRJIMÄTÖNTÄ LIIKUNTAKULTTUURIA RAKENNETAAN INTERSEKTIONAALISESTI}

Ehdotamme, että aikuisten ryhmäliikuntakäytäntöjä ryhdytään kehittämään vastuullisesti intersektionaalisen näkökulman avulla. Puhumme intersektionaalisen ryhmäliikuntapedagogiikan puolesta, koska risteävien erojen myöntäminen on ensimmäinen askel eriarvoisuutta tuottavien ryhmäliikuntakäytäntöjen purkamisessa. Väitämme, että ryhmäliikuntapalveluiden moniperusteista syrjintää ei osata havaita, ja konkreettisten uusien ohjausmenetelmien puuttuessa käytäntöjä ei pystytä muuttamaan, vaikka ongelmia havaittaisiin (ks. Markula \& Chikinda 2016).

Intersektionaalisen ryhmäliikuntapedagogiikan mallissamme siirrytään erottelevasta ja luokittelevasta inklusiiviseen eli kaikille yhteisesti tarjottua toimintaa painottavaan ajattelutapaan. Nykyään liikuntakäytännöissä ongelmien ajatellaan alkavan silloin, kun ryhmään osallistuu valtavirrasta jonkin eron vuoksi poikkeava liikkuja, jota varten on pyrittävä keksimään erityismenettelyjä yhdenvertaisuuden toteuttamiseksi. Intersektionaalisen ajattelumallin puitteissa on kuitenkin pidettävä yhdenvertaisuuden toteutumisen kannalta ongelmallisina sellaisia tilanteita, joissa inklusiivisesta lähtökohdasta poiketaan, eikä risteäviä eroja ja alati vaikuttavia valtasuhteita tunnusteta lähtökohtaisena liikuntaa luonnehtivana seikkana. Malli kääntää asetelman niin, että ongelmia ei paikanneta enää yksilökehoihin, vaan ne nähdään kollektiivisina ryhmäliikuntakulttuurin kehityshaasteina.

Ohjaajien toiminta vaikuttaa siihen, mitä tunneilla opitaan, miten siellä viihdytään ja missä määrin liikunta osallistaa. Parasta politiikkaa onkin suunnata toimia liikunta-alan ammattilaisten työotteen kehittämiseen. Alalle tarvitaan konkreettisia arviointityökaluja, joiden avulla ammattilaiset voivat tunnistaa erilaisten ohjaustoimien vaikutukset. Intersektionaalinen ryhmäliikuntapedagogiikka perustuu monitieteiseen teoriapohjaan ja vastaa tähän tarpeeseen.

Valtasuhteet vaikuttavat kaikissa ohjaus- ja opetustilanteissa (Saresma 2018). Siksi perustamme intersektionaalisen ryhmäliikuntapedagogiikan valtasuhteiden tietoiseen analyysiin. Huomio pitää siirtää uusien sorrettujen liikkujaryhmien etsimisestä ja nimeämisestä vaiettuihin vallan käyttäjiin ja liikuntakulttuurin hierarkkisiin järjestyksiin. Ryhmäliikuntaohjaajan valta-asemasta käsin toimivan olisi tärkeä tiedostaa, millaisia etuoikeutettuja asemia hänellä itsellään on, millaisiin normeihin hänen edustamansa liikuntaorganisaatio työntekijöitä kannustaa sekä miten ne vaikuttavat ohjaustapoihin ja asiakaskohtaamisiin.

\section{HUOMIO RAKENTEELLISIIN UUDISTUKSIIN JA PEDAGOGISEN OSAAMISEN KEHITTÄMISEEN}

Jos vähän liikkuvat suomalaiset halutaan saada mukaan liikuntaharrastuksiin, ryhmäliikunta keskeisenä aikuisväestön liikuttajana joutuu miettimään uusia ratkaisuja siihen, miten palvelut rakennettaisiin nykyistä saavutettavammiksi kaikille eroista riippumatta. 
Pelkästään yksilöohjaajiin kohdistuvilla muutospaineilla liikunnan yhdenvertaisuus ei lisäänny vaikuttavasti. Ryhmäliikuntakulttuuriin tarvitaan kattavampia rakenteellisia uudistuksia, kuten intersektionaalisten erojen tunnistamiseen fokusoivaa koulutusta ja monitieteisiä toimijaverkostoja, joissa liikunnan vastuullisesta kehittämisestä voidaan keskustella avarakatseisesti ja tuoreista näkökulmista.

Intersektionaalisuus toimii käsitteenä, jonka avulla eri tieteenalojen, hallintoalojen ja liikuntasektorien ymmärrystä yhdenvertaisuuden kysymyksistä voidaan yhdenmukaistaa. Liikuntakäytäntöjä raamittavien käsitteiden määrittelykeskustelu on tärkeää avata, koska ilman yhteistä kieltä eri tahot eivät pysty tekemään yhteistyötä vastuullisen liikuntakulttuurin saavuttamiseksi.

Intersektionaalisuus laajentaa sanavarastoamme, mutta käytäntöön tuotuna myös ajatteluamme. Intersektionaalisuus on jo mullistanut esimerkiksi sitä, miten oikeudellisia asioita lähestytään, ja nyt se voisi laajentaa aikuiskoulutuspolitiikan ymmärrystämme. Perinnäisten käsitteiden rinnalle tarvitaan intersektionaalisuuden käsitteen käyttöönottoa laajemmin kuin vain tutkimuskeskusteluissa.

Ryhmäliikuntaohjaajien ammattiosaamisen ja syrjimättömien ohjauskäytäntöjen kehittämisessä tulisi hyödyntää nykyistä enemmän pedagogista ajattelua. Ryhmäliikuntaa on totuttu vähättelemään tyhjänpäiväisenä jumppailuna, mutta liikunnan si- vistystehtävään kytkeytyviä päämääriä korostamalla ryhmäliikuntaohjaajuus työnä voi saada uudenlaista arvostusta ja kunnioitusta. Vastuullisen ryhmäliikuntapedagogiikan omaksumisesta on siten etua sekä liikkujille että ohjaajakunnalle itselleen.

Liikunnanohjaamisen tapakulttuuriin päädytään paljolti tiedostamattomien prosessien kautta. Siksi hyväntahtoisuuteen ja huomioivaan kohtaamiseen pyrkivä ohjaaminenkin voi tuottaa eriarvoistamista. Kehittämämme intersektionaalinen ryhmäliikuntapedagogiikka auttaa käsitteellistämään liikunnan eriarvoisuuksia ja tiedostamaan valta-asetelmia perustavina liikunnan vastuullisuuden kysymyksinä.

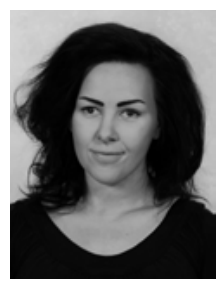

\section{KAISA-RIITTA AHO}

FM, väitöskirjatutkija, sukupuolentutkimus Turun yliopisto ryhmäliikuntaohjaaja (D) https://orcid.org/0000-00015072-4689

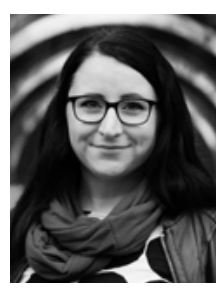

\section{HANNA HUUMONEN}

YTM, valtion liikuntaneuvoston jäsen ja neuvoston yhdenvertaisuuden, tasa-arvon ja kestävän kehityksen jaoston puheenjohtaja ryhmäliikuntaohjaaja

(D) https://orcid.org/0000-00022073-3880

\section{LÄHTEET}

Ayo, N. (2012). Understanding Health Promotion in a Neoliberal Climate and the Making of Health Conscious Citizens. Critical Public Health 22(1), 99-105.

Berg, P.; Lehtonen, K. \& Salasuo, M. (toim.) (2019). "Siitä on pikemminkin vaiettu." Kirjoituksia kiusaamisesta, syrjinnästä ja epäasiallisesta kohtelusta lasten ja nuorten liikunnassa ja urheilussa. Nuorisotutkimusverkosto / Nuorisotutkimusseura, verkkojulkaisuja 151. https://www.nuorisotutkimusseura.fi/images/ kuvat/verkkojulkaisut/kirjoituksia_kiusaamisesta_ syrjinnasta_ja_epaasiallisesta_kohtelusta_web.pdf.

Crenshaw, K. (1989). Demarginalizing the Intersection of Race and Sex: A Black Feminist Critique of
Antidiscrimination Doctrine, Feminist Theory and Antiracist Politics. University of Chicago Legal Forum 1989, 139-167.

Harjunen, H. (2019). Exercising Exclusions: Space, Visibility, and Monitoring of the Exercising Fat Female Body. Fat Studies 8(2), 173-186.

Hokka, L. (2014). Miesten ja naisten tasa-arvon edistäminen liikuntapolitiikassa. Hyviä käytäntöjä Suomessa, Ruotsissa ja Norjassa. Opetus- ja kulttuuriministeriön julkaisuja 2014:9.

Itkonen, H. \& Kauravaara, K. (2015). Tulkintojen jäljillä. Teoksessa H. Itkonen \& K. Kauravaara (toim.) Liikunta kansalaisten elämänkulussa. Tulkintoja liikkumisesta ja liikunnanedistämisestä. Liikunnan ja kansanterveyden julkaisuja 296. Jyväskylä: LIKES, 136-182. 
Kauravaara, K. \& Rönkkö, E. (2020). Näkymättömyys, marginalisaatio ja eronteot suomalaisessa liikuntakulttuurissa. Teoksessa J. Kokkonen \& K. Kauravaara (toim.) Eriarvoisuuden kasvot liikunnassa. Liikuntatieteellisen seuran julkaisuja 175, 229-251.

Koivisto, N. (2011). Näköaloja laaja-alaisiin tasaarvokysymyksiin. Kaikkien tasavertainen oikeus liikuntaan ja urheiluun. SLU-julkaisusarja 2011:5. Helsinki: Suomen liikunta ja urheilu ry.

Kokkonen, J. (2020). SUEK:in Nina Laakso: Eettisiä pohdintoja ei voi enää sivuuttaa urheilussa. Liikunta \& Tiede 57(2), 9-11.

Kokkonen, M. (2018). Seksuaalivähemmistöjen häirintä joukkueessa tai liikuntaryhmässä: henkisen pahoinvoinnin näkökulma. Liikunta \& Tiede 55(6), 96-102.

Kuusela, A. (2020). Filosofian keinoin eettisen valmentajan jäljillä. Liikunta \& Tiede 57(2), 54-55.

Leveälahti, S.; Savioja, H.; Hanhijoki, I. \& Nieminen, J. (2015). Esiselvitys aikuiskoulutuksen ennakointimallista. Raportit ja selvitykset 2015:1. Helsinki: Opetushallitus.

Liikuntalaki (2015). https://finlex.fi/fi/laki/alkup/2015/ 20150390 (21.8.2020)

Markula, P. \& Chikinda, J. (2016). Group Fitness Instructors as Local Level Health Promoters: A Foucauldian Analysis of the Politics of Health/Fitness Dynamic. International Journal of Sport Policy and Politics 8(4), 625-646.

Miltton (2017). Tutkimus: Vaikenemisen aika on ohi suomalaiset odottavat yrityksiltä yhteiskunnallisia kannanottoja sekä asiakkaina että työntekijöinä. https://news.cision.com/fi/miltton/r/tutkimus-vaikenemisen-aika-on-ohi---suomalaiset-odottavatyrityksilta-yhteiskunnallisia-kannanottoj,c2399858 (23.7.2020)

Nousiainen, K. (2012). Suomen syrjinnänvastainen lainsäädäntö. Tasa-arvo- ja yhdenvertaisuuslaki. Teoksessa J. Kantola, K. Nousiainen \& M. Saari (toim.) Tasa-arvo toisin nähtynä. Oikeuden ja politiikan näkökulmia tasa-arvoon ja yhdenvertaisuuteen. Tallinna: Gaudeamus, 143-174.

Parviainen, J. (2018). Embodying Industrial Knowledge: An Epistemological Approach to the Formation of Body Knowledge in the Fitness Industry. Sociology of Sport Journal 35(4), 358-366.
Pyykkönen, T. (2016). Yhdenvertaisuus ja tasa-arvotyö valtion liikuntapolitiikassa - taustaselvitys valtion liikuntaneuvostolle ja sen yhdenvertaisuus- ja tasaarvojaostolle. Valtion liikuntaneuvoston julkaisuja 2016:1.

Ruuskanen, T. (2019). Perinteinen kävelylenkkeily edelleen suosituin koko kansan liikuntaharrastus. http://tilastokeskus.fi/tietotrendit/artikkelit/2019/ perinteinen-kavelylenkkeily-edelleen-suosituin-kokokansan-liikuntaharrastus-1/ (6.7.2020).

Saresma, T. (2018). Intersektionaalisuus - erot ja hierarkiat opettamisessa. Teoksessa A. Laukkanen, S. Miettinen, A-M. Elonheimo, H. Ojala \& T. Saresma (toim.) Feministisen pedagogiikan ABC. Opas ohjaajille ja opettajille. Tampere: Vastapaino, 26-34.

Simien, E.; Arinze, N. \& McGarry, J. (2019). A Portrait of Marginality in Sport and Education: Toward a Theory of Intersectionality and Raced-Gendered Experiences for Black Female College Athletes. Journal of Women, Politics \& Policy 40(3), 409-427.

Skeggs, B. (1997). The Formation of Class and Gender: Becoming Respectable. London: Sage.

Thompson, J. (2000). Women, Class and Education. London: Routledge.

Tiihonen, A. (2014). Liikuntakulttuurin käsitteet muuttuvat ja muuttavat. Valtion liikuntaneuvoston julkaisuja 2014:6.

Trudel, R. \& Cotte, J. (2009). Does it Pay to Be Good? MIT Sloan Management Review 50(2), 61-68.

VNS 7/2010 vp. Valtioneuvoston selonteko naisten ja miesten välisestä tasa-arvosta. Sosiaali- ja terveysministeriön julkaisuja 2010:8.

VN 2020:19. Hyvinvoinnin ja tasa-arvon vahvistaminen koronakriisin aikana ja sen jälkeen. Valtioneuvoston julkaisuja 2020:19.

VN 2020. Suomi tasa-arvon kärkimaaksi. Hallituksen tasa-arvo-ohjelma 2020-2023. Valtioneuvoston periaatepäätös.

Yhdenvertaisuuslaki (2014). https://www.finlex.fi/fi/laki/ alkup/2014/20141325 (21.8.2020).

Zacheus T., Koski P. \& Mäkinen S. (2011). Naiset paitsiossa? Maahanmuuttajanaisten liikunnan tunnuspiirteitä Suomessa. Liikunta \& Tiede 48(1), 63-70. 